\title{
KAJIAN KEPARIWISATAAN UNTUK PENGEMBANGAN DAERAH TUJUAN WISATA YANG OPTIMAL DI KABUPATEN LAMONGAN
}

Oleh :

Sri Murtini

Jurusan Pendidikan Geografi FIS Unesa

\begin{abstract}
Abstrak
Penelitian ini bertujuan untuk: (1) mengetahui potensi daya tarik dan aksesibilitas obyek wisata Goa Maharani, Pantai Tanjung Kodok, Waduk Gondang, Makam Sunan Drajad, dan Makam Sendang Duwur (2) menentukan objek-objek wisata yang layak untuk dijadikan pusat pengembangan kepariwisataan di Kabupaten Lamongan.

Untuk mencapai tujuan tersebut, berbagai macam data dikumpulkan dengan cara observasi, wawancara, pengukuran dan dokumentasi. Selanjutnya data dianalisis dengan metode skoring untuk mengetahui tingkat potensi daya tarik dan pusat pengembangan obyek wisata, sedangkan analisis deskriptif digunakan untuk mengetahui tingkat aksesibilitas masing-masing lokasi obyek wisata. Penilaian tingkat kelayakan objek wisata didasarkan pada 25 komponen daya tarik wisata. Hasil penelitian menunjukkan bahwa Makam Sunan Drajad dan Waduk Gondang berpotensi baik, Pantai Tanjung Kodok dan Goa Maharani berpotensi sedang, Makam Sendang Duwur berpotensi rendah. Aksesibilitas lima obyek wisata yang diteliti dari kota Surabaya termasuk rendah, sedangkan dari kota Lamongan mempunyai aksesibilitas sedang. Dengan menggunakan 7 kriteria pengukuran maka dari ke lima obyek wisata, Goa Maharani dapat dijadikan pusat pertumbuhan kepariwisataan di Kabupaten Lamongan.
\end{abstract}

Kata Kunci: pengembangan, daerah tujuan wisata, aksesibilitas.

\section{Pendahuluan}

Pengembangan kepariwisataan merupakan salah satu usaha yang dapat dilakukan untuk mencapai masyarakat sejahtera, melalui berbagai kegiatan yang berkaitan dengan industri pariwisata. Industri pariwisata yang berkembang akan berperan dalam peningkatan pendapatan masyarakat yang terlibat didalamnya dan secara tidak langsung bagi masayakat lainnya. 
Kajian Kepariwisataan Untuk Pengembangan Daerah Tujuan Wisata

Yang Optimal Di Kabupaten Lamongan

Kepariwisataan yang berkembang baik diharapkan akan dapat menarik wisatawan, baik wisatawan domestik maupun wisatawan mancanegara dalam jumlah yang cukup banyak. Dengan demikian akan banyak peluang kerja yang dapat disediakan melalui pelayanan segala kebutuhan wisatawan. Disamping itu dari kontribusi wisatawan akan diperoleh devisa baik untuk daerah maupun negara. Hal itu dapat diupayakan melalui pengembangan obyek-obyek wisata di suatu daerah.

Kabupaten Lamongan mempunyai beberapa obyek wisata andalan yang diharapkan dapat memberikan kontribusinya terhadap pendapatan daerah. Di antara obyek wisata andalan tersebut adalah Goa Maharani, Komplek Makam Sunan Dradjad, Sendang Duwur, Tanjung Kodok dan Waduk Gondang, sedangkan yang lain misalnya, Monumen Tenggelamnya Kapal Van Der Wiejck, Sendang Pucakwangi, Sumber Air Panas Tepanas dan sebagainya merupakan obyek-obyek wisata yang juga menarik untuk dinikmati, namun belum dikelola lebih lanjut.

Dari sekian banyak obyek wisata yang ada di Kabupaten Lamongan, beberapa lokasi obyek wisata mulai dikembangkan, misalnya Goa Maharani dan Pantai Tanjung Kodok sedangkan yang lain belum dikembangkan dengan sungguh-sungguh mengingat beberapa kendala yang ada, misalnya dana dan sumber daya manusianya. Meskipun banyak terdapat obyek wisata namun jumlah kunjungan wisata ke obyek wisata di Kabupaten Lamongan belum menggembirakan. Dari berbagai jenis obyek wisata tersebut, jumlah wisata yang berkunjung rata-rata kurang dari 300.000 wisatawan per tahun, jauh lebih kecil daripada wisatawan yang berkunjung ke kebun Binatang Surabaya yaitu sebesar dua juta lebih ratarata per tahunnya.

Sementara itu lokasi wisata di Kabupaten Lamongan, tidak begitu jauh dari Surabaya yang merupakan pintu gerbang wisatawan asing maupun wisatawan dalam negeri khususnya dari luar pulau Jawa. Dengan demikian obyek-obyek wisata di Kabupaten Lamongan mempunyai peluang yang besar untuk menarik wisatawan dari Surabaya. Untuk mencapai hal itu obyek-obyek wisata di Kabupaten Lamongan perlu dikembangkan lebih lanjut supaya lebih menarik.

Untuk mengembangkan seluruh obyek wisata di kabupaten diperlukan sejumlah biaya yang cukup besar. Mengingat kondisi pemerintah saat ini yang masih dalam kondisi krisis sehingga dana untuk pembangunan kepariwisatan relatif terbatas, maka diperlukan upaya lain untuk pengembangannya. Dengan maksud untuk mendapatkan hasil yang maksimal meskipun modal yang digunakan untuk pengembangan kepariwisataan relatif terbatas. 
Dalam bidang kepariwisataan, untuk mengembangkan lokasi obyek wisata menjadi daerah tujuan wisata yang menarik perlu memperhatikan beberapa aspek yaitu : 1) obyek wisata yang meliputi bentuk, jenis, dan persebaran, 2) elemen-elemen penawaran meliputi atraksi, transportasi, infrastruktur, akomodasi dan fasilitas penunjang yang lain, 3) wisatawan sebagai konsumen obyek wisata (Pearce, D, 1986).

Selanjutnya Pendit (2003) menjelaskan bahwa suatu daerah wisata disamping akomodasi atau hotel atau tempat menginap akan disebut daerah tujuan wisata apabila memiliki atraksi-atraksi yang memikat sebagai tujuan kunjungan wisata, panorama keindahamn alam yang menakjubkan seperti gunung, lembah, ngarai, air terjun, danau, matahari terbit atau terbenam dan lain-lain yang berkaitan dengan alam sekitarnya. Ada 3 kebutuhan utama yang karena dipenuhi suatu daerah yang akan menjadi tujuan wisata yaitu :1) memiliki atraksi dan obyek wisata yang menarik, 2) mudah dicapai dengan alat-alat kendaraan, 3) tersedianya tempat untuk tinggal sementara.

Pengembangan Daerah Tujuan Wisata merupakan usaha memperluas kawasan atau lokasi obyek wisata atau menambah berbagai macam kebutuhan wisatawan yang dapat dilakukan dengan berbagai cara, misalnya dengan mengembangkan sarana transportasi, infrastruktur, fasilitas penunjang dan pelayanan, akomodasi maupun adanya berbagai atraksi. Untuk itu diperlukan kajian yang mendalam tentang potensi suatu daerah tujuan wisata.

Berbagai faktor dapat digunakan untuk pengukuran potensi daerah tujuan wisata, misalnya iklim, keindahan alam, adat istiadat, seni bangunan, pentas seni, pameran, pekan raya, peninggalan sejarah/purbakala, kegiatan masyarakat, fasilitas olah raga dan edukasi untuk rekreasi, kesehatan, belanja, hiburan, infrastruktur, pangan dan akomodasi serta faktor keamanan (Pearce, 1995).

Charles, E.G. (1996) menjelaskan bahwa obyek wisata yang menarik mempunyai daya tarik besar untuk mendatangkan wisatawan. Oleh karena itu evaluasi potensi obyek wisata perlu dilakukan terutama untuk pengembangan kepariwisataan yang optimal.

Keterjangkauan merupakan sisi lain yang juga mempengaruhi pasar (wisatawan), keterjangkauan merupakan jauh dekatnya pasar yang diukur dengan waktu perjalanan, biaya perjalanan atau jarak perjalanan. Pada tingkat internasional diukur dari jauh dekatnya dari negara-negara industri atau negara kota dengan standar kehidupan yang tinggi sedangkan untuk tingkat regional atau nasional adalah jauh dekatnya dengan daerah urban yang besar dan karakteristik penduduk seperti 
Kajian Kepariwisataan Untuk Pengembangan Daerah Tujuan Wisata

Yang Optimal Di Kabupaten Lamongan

umur dan penghasilan. Untuk tingkat lokal diukur dari jauh dekatnya daerah tujuan wisata dengan kota kecil atau setingkat ibukota kabupaten atau propinsi (Pearce, 1986).

Keterjangkauan atau aksesibilitas merupakan faktor yang penting dalam mengembangkan daerah tujuan wisata. Daerah Tujuan Wisata yang mudah dijangkau oleh wisatawan memiliki nilai yang tinggi. Suharyono dan Amin (1994) menjelaskan bahwa, keterjangkauan tidak selalu terkait dengan jarak, tetapi berkaitan dengan kondisi medan, ada tidaknya sarana transportasi atau komunikasi; keterjangkauan berubah dengan adanya perkembangan perekonomian dan kemajuan teknologi.

Menurut Sujali (1989), pengembangan kepariwisataan mendasarkan pada sifat, fungsi, kemampuan, jangkauan pemasaran dapat bersifat lokal, regional, nasional dan bahkan dapat bersifat internasional. Pengembangan tersebut dapat dilaksanakan diantaranya dengan beberapa teori kutub pertumbuhan atau dengan konsep tempat sentral dari Christaller.

Kabupaten Lamongan mempunyai banyak obyek wisata, diantaranya ada yang telah dikembangkan dan ada yang belum dikembangkan mengingat beberapa kendala yang ada misalnya dana dan sumberdaya manusianya. Meskipun banyak terdapat banyak obyek wisata namun jumlah kunjungan wisata ke obyek wisata di Kabupaten Lamongan belum menggembirakan. Paling banyak wisatawan berkunjung ke Makam Sunan Drajad yaitu rata-rata dibawah 400.000 wisatawan per tahun, sedangkan obyek wisata lain kurang dari itu.

Sementara itu jumlah wisatawan yang berkunjung ke Kebun Binatang Surabaya rata-rata 2 juta wisatawan per tahun, dan Kabupaten Lamongan dapat dijangkau dari Surabaya yang merupakan pintu gerbang ke Jawa Timur. Dengan demikian obyek-obyek wisata di Kabupaten Lamongan mempunyai peluang yang besar untuk menarik wisatawan dari Surabaya.

Dengan menerapkan teori Kutub Pertumbuhan yang dioperasikan atas konsep leading industry, polarization dan spread effect dan teori Tempat Sentral yang dioperasikan atas dasar prinsip pemasaran, transportasi dan administrasi, maka dalam pengembangan obyek-obyek wisata di Kabupaten Lamongan harus dalam satu pengembangan.

Berdasarkan teori diatas, di Kabupaten Lamongan perlu dikembangkan satu obyek yang mempunyai potensi daya tarik wisata paling besar untuk dijadikan pusat kegiatan kepariwisataan yang merupakan Daerah Tujuan Wisata yang paling menarik. Dari pusat kegiatan ini, diasumsikan dapat mempengaruhi kehidupan obyek wisata 
yang lain yang ada sekitarnya melalui kunjungan wisatawan sekitarnya. Proses tersebut dapat berlangsung dengan baik apabila sarana dan prasarana transportasi tersedia dengan baik.

\section{Metode Penelitian}

Penelitian ini dilakukan di 5 lokasi obyek wisata di Kabupaten Lamongan yaitu Goa Maharani, Pantai Tanjung Kodok, Waduk Gondang, Makam Sunan Drajad dan Makam Sendang Duwur. Pemilihan lokasi tersebut dilakukan dengan pertimbangan bahwa 5 lokasi tersebut merupakan obyek wisata yang relatif banyak dikunjungi wisatawan dan hampir setiap hari dikunjungi wisatawan.

Data hasil pemilihan diambil dengan cara observasi, wawancara, pengukuran dan dokumentasi. Observasi dilakukan untuk memperoleh data ada tidaknya fasilitas penunjang pariwisata, atraksi, kondisi lingkungan dan topografi secara umum. Wawancara dilakukan terhadap pengelola masing-masing lokasi wisata untuk mengetahui kondisi keamanan dan perilaku wisatawan dalam kaitannya dengan keutuhan obyek wisata. Dokumentasi diperlukan untuk mengetahui jumlah wisatawan, luas lahan, kasus pencurian dan kecelakaan. Pengukuran dilakukan untuk mengetahui jumlah kotoran/sampah di lokasi wisata, waktu dan jarak antar obyek wisata.

Data hasil penelitian selanjutnya dianalisis sesuai dengan tujuan penelitian. Untuk mengetahui potensi daya tarik wisata dilakukan skoring untuk setiap komponen daya tarik, skor 1 apabila komponen tersebut ada lokasi obyek wisata dan skor 0 apabila tidak ada. Dalam penelitian ini digunakan 25 komponen daya tarik yaitu : 1) tempat penginapan, 2) rumah makan, 3) tempat hiburan/kesenian, 4) tempat pameran, 5) tempat istirahat, 6) tempat olah raga, 7) tempat rekreasi edukasi, 8) tempat ibadah, 9) fasilitas kesehatan, 10) keamanan, 11) komunikasi, 12) kendaraan umum, 13) taman, 14) listrik, 15) air, 16) tempat belanja, 17) tempat peninggalan sejarah, 18) seni bangunan, 19) kegiatan peribadatan, 20) pagelaran/pentas seni, 21) pekan raya komersial, 22) makanan lokal, 23) pakaian lokal, 24) kerajinan tangan, 25) tempat parkir.

Tingkat potensi wisata dapat diketahui dari sejumlah komponen wisata yang ada di lokasi obyek wisata. Potensi sangat baik apabila terdapat 21-25 komponen wisata, potensi baik apabila skor 16-20, potensi sedang apabila skor 11-15, potensi buruk apabila skor 6-10, dan potensi sangat buruk apabila skor 0-5. 
Kajian Kepariwisataan Untuk Pengembangan Daerah Tujuan Wisata

Yang Optimal Di Kabupaten Lamongan

Untuk mengetahui aksesibilitas masing-masing lokasi obyek wisata ditentukan berdasarkan jarak tempuh dalam $\mathrm{km}$ dan waktu tempuh dalam menit dari lokasi obyek wisata sampai ibukota Kabupaten Lamongan, Gresik, Tuban dan ibukota propinsi yaitu Surabaya. Selanjutnya tingkat aksesibilitasnya ditentukan berdasarkan kriteria aksesibilitas tinggi, sedang dan rendah.

1. Aksesibilitas tinggi apabila jarak tempuh antara $25-50 \mathrm{~km}$ dengan waktu tempuh 30-60 menit atau jarak tempuh kurang dari $25 \mathrm{~km}$ dengan waktu tempuh 30-60 menit, atau jarak tempuh $25-50 \mathrm{~km}$ dengan waktu tempuh kurang dari 30 menit.

2. Aksesibilitas sedang apabila jarak tempuh antara $25-50 \mathrm{~km}$ dengan waktu tempuh 30-60 menit atau jarak tempuh kurang dari $25 \mathrm{~km}$ dengan waktu tempuh lebih dari 60 menit, atau jarak tempuh lebih dari $50 \mathrm{~km}$ dengan waktu tempuh kurang dari 30 menit.

3. Aksesibilitas rendah apabila jarak tempuh antara $25-50 \mathrm{~km}$ dengan waktu tempuh lebih dari 60 menit atau jarak tempuh lebih dari $50 \mathrm{~km}$ dengan waktu tempuh antara 30-60 menit, atau jarak tempuh lebih dari $50 \mathrm{~km}$ dengan waktu tempuh lebih dari 30 menit.

Untuk menentukan lokasi obyek wisata yang dapat dijadikan pusat pertumbuhan kepariwisataan dilakukan penskoran indikator pertumbuhan yang meliputi kondisi alam, tingkat kemiringan medan, jarak antar obyek wisata, tingkat pencemaran, tingkat keamanan, perilaku wisatawan dan jumlah wisatawan. Skor masing-masing indikator berkisar antara 1-5 sesuai dengan peringkat dari 5 obyek wisata. Selanjutnya skor seluruh indikator untuk setiap lokasi obyek wisata dijumlahkan. Skor paling tinggi dipilih sebagai pusat pertumbuhan. Untuk mengetahui peringkat yang diperoleh setiap lokasi obyek wisata pada masing-masing indikator dapat diketahui seperti berikut ini :

1. Indikator kondisi alam ditunjukkan oleh luas lahan yang dipunyai kawasan obyek wisata, makin luas lahan yang dipunyai skornya makin tinggi

2. Tingkat kemiringan medan diketahui berdasarkan variasi topografi pada lokasi obyek wisata. Makin banyak terdapat perbukitan berarti variasi topografi makin banyak sehingga skornya makin tinggi.

3. Jarak antar obyek wisata, ditentukan berdasarkan jauh dekatnya ratarata dari suatu lokasi obyek wisata terhadap 4 obyek wisata yang lain. Jarak makin dekat skornya makin tinggi.

4. Tingkat pencemaran, diketahui berdasarkan banyak sedikitnya sampah di lokasi wisata, makin banyak sampah yang ada skor makin rendah. 
5. Tingkat keamanan, diketahui berdasarkan frekuensi terjadinya kecelakaan/bencana dan kejahatan, makin sedikit frekuensi kejadiannya makin tinggi skornya.

6. Perilaku wisatawan diketahui berdasarkan keutuhan obyek wisata. Skor makin tinggi apabila obyek wisata makin sedikit mengalami coretan, perusakan, pencurian barang milik kawasan obyek wisata.

7. Jumlah wisatawan diketahui berdasarkan jumlah wisatawan yang berkunjung selama 5 tahun terakhir, makin banyak jumlah wisatawan makin tinggi skornya.

\section{Hasil Penelitian dan Pembahasan}

Dari 5 lokasi obyek wisata yang diteliti, terdapat 2 lokasi kawasan wisata yang mempunyai kesamaan jenis yaitu Makam Sunan Drajad dan Makam Sendang Duwur sebagai wisata ziarah, sedangkan 3 obyek wisata yang lain menunjukkan karakter yang berbeda.

Selanjutnya, karakteristik obyek-obyek wisata di Kabupaten Lamongan dapat diketahui seperti berikut ini :

\section{Goa Maharani}

Merupakan obyek wisata alam yang mengandalkan atraksi alami berupa ornamen-ornamen yang terbentuk secara alamiah di goa karst sebagai atraksi utamanya. Dalam perkembangan selanjutnya ditambah dengan atraksi-atraksi yang lain.

Dari 25 komponen daya tarik untuk pengukuran potensi wisata, di kawasan wisata Goa Maharani terdapat 15 komponen, yaitu : 1) warung makan, 2) tempat duduk berpeneduh, 3) mushola, 4) pos penjagaan, 5) wartel, 6) kendaraan angkutan umum, 7) tempat bermain, 8) listrik, 9) air, 10) toko, 11) tempat parkir, 12) kamar mandi dan WC, 13) produk minuman lokal, 14) produk pakaian lokal dan 15) tempat hiburan/kesenian. Berdasarkan kriteria yang digunakan maka potensi daya tarik wisata Goa Maharani termasuk sedang.

Untuk menuju lokasi wisata Goa Maharani, dari Surabaya dapat ditempuh dalam waktu 100 menit melalui Gresik dengan jarak tempuh $75 \mathrm{~km}$ sedangkan dari Gresik ditempuh dalam waktu 70 menit dengan jarak tempuh $51 \mathrm{~km}$. Dari kota Tuban berjarak $30 \mathrm{~km}$ dengan waktu tempuh kurang lebih 40 menit, sedangkan dari Lamongan berjarak $41 \mathrm{~km}$ dengan waktu 60 menit. Berdasarkan jarak dan waktu tempuh tersebut, apabila dijangkau dari ibukota kabupaten terdekat yaitu Lamongan, Gresik dan Tuban mempunyai aksesibilitas sedang, namun apabila dijangkau dari Surabaya tingkat aksesibilitasnya rendah. 
Kajian Kepariwisataan Untuk Pengembangan Daerah Tujuan Wisata

Yang Optimal Di Kabupaten Lamongan

Indikator untuk penentuan pusat pengembangan kepariwisataan menunjukkan hasil seperti berikut :

a. Kondisi Alam, kawasan wisata Goa Maharani relatif jauh dari permukiman penduduk, kondisi sekitarnya berupa terjalan. Luas kawasan wisata secara keseluruhaan sekitar $5200 \mathrm{~m}^{2}$.

b. Variasi Topografi, apabila pemandangan hanya sebatas kawasan wisata maka variasi topografi relatif sedikit, namun apabila pemandangan diperluas terlihat adanya variasi topografi yang lebih beragam.

c. Jarak Antar Obyek Wisata, jarak dari Goa Maharani menuju Pantai Tanjung Kodok, Makam Sunan Drajad, Makam Sendang Duwur dan Waduk Gondang secara berurutan adalah 0,5 km, 4 km, $5 \mathrm{~km}$ dan $52 \mathrm{~km}$ sehingga rata-ratanya 15,375 km.

d. Tingkat Pencemaran, bahan-bahan pencemar berupa sampah dari bungkus makanan dan daun-daun pepohonan yang berguguran. Berhubung tidak cukup tersedia tenaga untuk selalu membersihkan sampah di kawasan wisata Goa Maharani yang relatif sedikit. Hasil pengukuran diperoleh sampah sebanyak 1,0 gram per $\mathrm{m}^{2}$.

e. Perilaku Wisatawan, selama 5 tahun terakhir di kawasan wisata Goa Maharani tidak pernah terjadi perusakan maupun pencurian namun wisatawan melakukan corat-coret di 2 lokasi yaitu tempaat peturasan dan tempat bermain.

f. Tingkat Keamanan, selama 5 tahun terakhir frekuensi terjadinya kejahatan rata-rata 3,2 kali berupa pencurian atau pencopetan dan kecelakaan adalah 3 kali tiap tahun berupa terpeleset dan jatuh dari tangga.

g. Jumlah Wisatawan, selama 15 tahun terakhir, jumlah wisatawan yang berkunjung rata-rata sebanyak 302-226 wisatawan tiap tahun.

\section{Makam Sunan Drajad}

Merupakan obyek wisata ziarah, khususnya untuk pemeluk agama Islam, dengan maksud mendoakan Sunan Drajad sebagai penyebar agama Islam. Seiring dengan perkembangan jumlah wisatawan, dibangun berbagai fasilitas untuk memenuhi kebutuhan pengunjung.

Di kawasan wisata Makam Sunan Drajad terdapat 20 komponen daya tarik sehingga digolongkan berpotensi baik untuk pengembangan pariwisata di Kabupaten Lamongan.

Jarak terpendek dari kota Surabaya ditempuh dalam waktu 100 menit dengan jarak $72 \mathrm{~km}$, dan dari Gresik berjarak $48 \mathrm{~km}$ dengan waktu 
tempuh 70 menit, dari Tuban berjarak $34 \mathrm{~km}$ dengan waktu tempuh 45 menit, sedangkan dari Lamongan berjarak $41 \mathrm{~km}$ dengan waktu tempuh 60 menit. Dengan demikian dari Surabaya dan Gresik mempunyai tingkat aksesibilitas rendah, sedangkan dari Tuban dan Lamongan tingkat aksesibilitasnya sedang.

Karakteristik kawasan obyek wisata Makam Sunan Drajad adalah sebagai berikut:

a. Kondisi Alam, kawasannya relatif datar dan luas, disekitarnya berupa lahan pertanian, pemukiman dan lautan. Secara keseluruhan luas kawasan wisata Makam Sunan Drajad adalah $7500 \mathrm{~m}^{2}$.

b. Variasi Topografi, karena permukaan lahannya relatif datar dan merata maka variasi topografinya relatif sedikit.

c. Jarak Antar Obyek Wisata, jarak dari kawasan wisata Makam Sunan Drajad ke Goa Maharani , Pantai Tanjung Kodok, Makam Sendang Duwur dan Waduk Gondang secara berurutan adalah $4 \mathrm{~km}, 4,5 \mathrm{~km}, 9 \mathrm{~km}$ dan $47 \mathrm{~km}$ sehingga rata-ratanya adalah $16,125 \mathrm{~km}$.

d. Tingkat Pencemaran, bahan-bahan pencemar berupa sampah bekas bungkus makanan dan daun yang gugur dari pohon. Hasil pengukuran sampah secara acak diperoleh rata-rata berat sampah 1,5 gram per $\mathrm{m}^{2}$.

e. Tingkat Keamanan, selama 5 tahun terakhir terjadi rata-rata 2 kali kejahatan per tahun berupa pencopetan, sedangkan kecelakaan tidak pernah terjadi.

f. Perilaku Wisatawan, selama 5 tahun terakhir tidak pernah terjadi gangguan terhadap kawasan wisata yang dilakukan oleh wisatawan.

g. Jumlah Wisatawan, slama 5 tahun terakhir jumlah wisatawan yang berkunjung rata-rata sebanyak 347.977 tiap tahun.

\section{Pantai Tanjung Kodok}

Merupakan obyek wisata alam yang mengandalkan pemandangan pantai sebagai atraksi utamanya. Dalam perkembangannya dibangun pula atraksi tambahan baik di darat maupun di alut serta tempat ruk'yat untuk penentu awal bulan Ramadhan dan hari raya led.

Di kawasan wisata Pantai Tanjung Kodok terdapat 13 komponen daya tarik wisata, sehingga dapat digolongkan pada potensi sedang.

Dari Surabaya berjarak 76 km dengan waktu tempuh 100 menit, dari Gresik berjarak $52 \mathrm{~km}$ dengan waktu tempuh 70 menit, dari Tuban berjarak $29 \mathrm{~km}$ dengan waktu tempuh 40 menit, sedangkan dari 
Kajian Kepariwisataan Untuk Pengembangan Daerah Tujuan Wisata

Yang Optimal Di Kabupaten Lamongan

Lamongan berjarak $42 \mathrm{~km}$ dengan waktu tempuh 60 menit. Dengan demikian tingkat aksesibilitas dari surabaya dan Gresik termasuk rendah, dari Lamongan termasuk sedang dan dari Tuban termasuk aksesiilitas tinggi.

Karakteristik kawasan wisata Pantai Tanjung Kodok adalah sebagai berikut :

a. Kondisi Alam, terdiri dari 2 bagain yaitu bagian laut dan daratan. Pada bagian daratan berupa daerah bergelombang merupakan tempat rekreasi, daratan ini cukup luas yaitu $21.000 \mathrm{~m}^{2}$.

b. Jarak Antar Obyek Wisata, jarak dari kawasan wisata Pantai Tanjung Kodok ke Goa Maharani, Makam Sunan Drajad, Makam Sendang Duwur dan Waduk Gondang secara berurutan adalah 0,5 $\mathrm{km}, 4,5 \mathrm{~km}, 4,5 \mathrm{~km}$, dan $52,5 \mathrm{~km}$ dengan jarak rata-ratanya adalah $15,5 \mathrm{~km}$.

c. Variasi Topografi, permukaan lahan kawasan wisata sangat bervariasi akibat pengaruh gelombang laut maupun air hujan. Bentuk lahan yang terjadi bermacam-macam.

d. Tingkat Pencemaran, sampah hasil aktivitas wisatawan tersebar di banyak tempat sehingga kawsan wisata tampak kotor. Hasil pengukuran diperoleh sampah sebanyak 4,0 gram per $\mathrm{m}^{2}$.

e. Perilaku Wisatawan, selama 5 tahun terakhir tidak dijumpai adanya kasus perusakan maupun pencurian barang milik kawasan wisata, namun corat-coret masih terjadi yang dilakukan di 3 lokasi.

f. Tingkat Keamanan, selama 5 tahun terakhir terjadi gangguan keamanan sebanyak rata-rata 4,2 kali per tahun berupa pencopetan, dan kecelakaan terjadi rata-rata sebanyak 3,6 kali per tahun berupa terpeleset dan jatuh dari tebing.

g. Jumlah Wisatawan, selama 5 tahun terakhir jumlah wisatawan yang berkunjung rata-rata sebanyak 187.888 wisatawan per tahun.

\section{Makam Sendang Duwur}

Merupakan obyek wisata ziarah untuk pemeluk Islam. Fasilitas kepariwisataan tidak banyak dikembangkan karena hanya untuk keperluan ziarah.

Berdasarkan hasil observasi, di kawasan Makam Sendang Duwur hanya terdapat 10 komponen daya tarik wisata sehingga kawasan ini digolongkan berpotensi buruk.

Untuk menuju ke lokasi Makam Sendang Duwur tidak ada kendaraan umum. Jarak dari Tuban adalah $30 \mathrm{~km}$ dengan waktu 
tempuh $45 \mathrm{~km}$, dari Gresik dengan jarak $55 \mathrm{~km}$ ditempuh selama 80 menit, dari Surabaya dengan jarak $80 \mathrm{~km}$ ditempuh dalam waktu 110 menit dan dari Lamongan dengan jarak $45 \mathrm{~km}$ ditempuh dalam waktu 70 menit. Dengan demikian tingkat akssibilitas Makam Sendang Duwur dari Surabaya, Gresik dan Lamongan termasuk tingkat rendah, sedang dari Tuban aksesibilitasnya tinggi.

Karakteristik kawasan wisata Makam Sendang Duwur adalah sebagai berikut :

a. Kondisi Alam, terletak di bagian atas perbukitan dan berada di lingkungan permukiman penduduk. Luas kompleks Makam Sendang Duwur relatif sempit yaitu $1700 \mathrm{~m}^{2}$.

b. Variasi Topografi, permukaan lahan kawasan Makam Sendang Duwur tidak datar, namun karena arealnya sempit variasi topografinya tidak tampak, kecuali jika jarak penglihatan diperluas akan tampak variasi topografinya.

c. Jarak antar Obyek Wisata, jarak dari Mmakam Sendang Duwur ke Pantai Tanjung Kodok, Goa Maharani, Makam Sunan Drajad dan Waduk Gondang adalah 4,5 km, 5 km, $9 \mathrm{~km}$ dan $56 \mathrm{~km}$, sehingga jarak rata-ratanya adalah $18,625 \mathrm{~km}$.

d. Tingkat Pencemaran, kondisi di dalam komplek makam relatif bersih dari sampah, namun di luar makam sampah plastik, kertas maupun daun masih berserakan, hasil pengukuran menunjukkan jumlah sampah yang ada sebanyak 1,5 gram per $\mathrm{m}^{2}$.

e. Perilaku Wisatawan, selama 5 tahun terakhir tidak pernah terjadi perilaku negatif dari wisatawan namun masih terdapat corat-coret pada kamar mandi.

f. Tingkat Keamanan, selama 5 tahun terakhir tidak pernah terjadi gangguan keamanan terhadap wisatawan namun masih terjadi kecelakaan yaitu jatuh terpeleset yang kejadiannya rata-rata sebanyak 1,2 tiap tahun.

g. Jumlah Wisatawan, jumlah wisatawan yang berkunjung relatif sedikit, selama 5 tahun terakhir wisatawan yang berkunjung sebanyak 9.785 orang tiap tahun.

\section{Waduk Gondang}

Merupakan obyek wisata buatan, dan atraksi yang ada belum dikembangkan secara optimal. Atraksi wisata masih menggantungkan pada wisata air dan taman yang relatif tidak luas dan tidak beragam isinya. Komponen daya tarik yang terdapat di kawasan wisata Waduk Gondang sebanyak 18 buah, sehingga kawasan ini dapat digolongkan berpotensi baik, dan dapat dikembangkan lebih lanjut. 
Kajian Kepariwisataan Untuk Pengembangan Daerah Tujuan Wisata

Yang Optimal Di Kabupaten Lamongan

Jarak terpendek dari Surabaya menuju Waduk Gondang adalah 85 km dengan waktu tempuh 75 menit, dari Gresik berjarak 102 km dengan waktu tempuh 150 menit dan dari Tuban berjarak $82 \mathrm{~km}$ dengan waktu tempuh 110 menit. Berdasarkan jarak dan waktu tempuh tersebut aksesibilitas dari kota-kota tersebut adalah rendah.

Karakteristik kawasan wisata Waduk Gondang adalah sebagai berikut :

a. Kondisi Alam, perairan waduk tidak begitu luas dan tidak dalam, pada waktu surut digunakan sebagai lahan pertanian. Areal kawasan wisata Waduk Gondang cukup luas yaitu $11.000 \mathrm{~m}^{2}$ pada bagian daratan.

b. Variasi Topografi, kawasan waduk terletak pada daerah yang relatif datar, hanya tampak tonjolan tanah berupa tanggul penahan air, sehingga secara keseluruhan tidak tampak adanya variasi topografi.

c. Jarak Antar Obyek Wisata, jarak dari Waduk Gondang ke Makam Sunan Drajad, Pantai Tanjung kodok, Makam Sendang Duwur adalah $47 \mathrm{~km}, 52 \mathrm{~km}, 52,5 \mathrm{~km}$ dan $56 \mathrm{~km}$ sehingga jarak rataratanya adalah $51,875 \mathrm{~km}$.

d. Tingkat Pencemaran, sampah hasil aktivitas wisatawan dan daundaun yang berguguran nampak berserakan secara merata dalam jumlah cukup banyak. Hasil pengukuran diperoleh sampah sebanyak 3,0 gram per $\mathrm{m}^{2}$.

e. Tingkat Keamanan, slama 5 tahun terakhir gangguan keamanan terhadap wisatawan tidak terjadi namun masih terjadi kecelakaan yaitu wisatawan tercebur ke waduk sebanyak 2 kali.

f. Perilaku Wisatawan, selama 5 tahun terakhir tidak dijumpai kasus pencurian maupun perusakan barang-barang milik kawasan wisata begitu pula dengan corat-coret.

g. Jumlah Wisatawan, selama 5 tahun terakhir wisatawan yang berkunjung ke waduk Gondang rata-rata sebanyak 46.814 orang per tahun.

Berdasakan kondisi alam masing-masing kawasan wisata khususnya luas areal, maka skor 5 diperoleh Pantai Tanjung Kodok, sedangkan Waduk Gondang skor 4 Makam Sunan Drajad skor 3, Goa Maharani skor 2 dan Makam Sendang Duwur skor 1.

Berdasarkan tingkat pencemaran yang terjadi, yang apling sedikit terdapat sampah dengan skor 5 adalah Goa maharani, skor 4 Waduk Gondang, skor 3 Makam Sunan Drajad, skor 2 Makam Sendang Duwur, skor 1 Pantai Tanjung Kodok. 
Berdasarkan kondisi keamanan, yang paling sedikit terjadi gangguan keamanan diberi skor 5 yaitu Waduk Gondang, berikutnya skor 4 Makam Sendang Duwur, skor 3 Makam Sunan Drajad, skor 2 Goa Maharani dan skor 1 Pantai Tanjung Kodok.

Berdasarkan perilaku wisatawan, skor tertinggi sebanyak 5 untuk kawasan wisata yang paling sedikit mengalami gangguan dari wisatawan yaitu Makam Sunan Drajad, dan Waduk Gondang sehingga keduanya memperoleh skor sama yaitu 4,5, berikutnya adalah skor 3 Makam Sendang Duwur, skor 2 Goa Maharani dan skor 1 Pantai Tanjung Kodok.

Jarak rata-rata antar obyek paling dekat diberi skor 5 yaitu Goa Maharani, skor 4 Makam Sunan Drajad, skor 3 Pantai Tanjung Kodok, skor 2 Makam Sendang Duwur dan skor 1 Waduk Gondang.

Skor tertinggi yaitu 5 diberikan kepada kawasan wisata yang dikunjungi oleh paling banyak wisatawan yaitu Makam Sunan Drajad, berikutnya skor 4 Goa Maharani, skor 3 Pantai Tanjung Kodok, skor 2 Makam Sendang Duwur dan skor 1 Waduk Gondang.

Dengan menjumlah skor yang diperoleh masing-masing kawasan wisata maka skor tertinggi adalah kawasan wisata Goa Maharani dengan jumlah skor 24, sehingga kawasan ini dapat dijadikan pusat pengembangan kepariwisataan Kabupaten Lamongan.

Meskipun Goa Maharani merupakan kawasan yang terbaik diantara kawasan yang lain, masih terdapat keterbatasan yang perlu diatasi misalnya potensi daya tarik wisata yang termasuk sedang dan tingkat aksesibilitas juga sedang. Untuk potensi daya tarik relatif lebih mudah mengatasinya yaitu dengan menambah beberapa fasilitas penunjang kepariwisataan di kawasan wisata Goa Maharani. Namun tidak demikian dengan tingkat aksesibilitas yang sangat tergantung dari kondisi medan dan teknologi, keduanya sangat mahal biayanya.

Untuk pengembangan selanjutnya diperlukan pemilihan atraksi tambahan yang tepat dan penambahan fasilitas penunjang kepariwisataan yang memadai. Selalu diperlukan berbagai inovasi dalam pengembangannya sehingga dapat memuaskan wisatawan dari berbagai kalangan.

\section{Simpulan Dan Saran}

Berdasarkan hasil penelitian maka dapat ditarik kesimpulan:

1. Dari 5 kawasan obyek wisata, 2 kawasan berpotensi baik, yaitu Makam Sunan Drajad dan Waduk Gondang, 2 kawasan berpotensi 
Kajian Kepariwisataan Untuk Pengembangan Daerah Tujuan Wisata

Yang Optimal Di Kabupaten Lamongan

sedang yaitu Pantai Tanjung Kodok dan Goa Maharani, sedangkan Makam Sendang Duwur berpotensi rendah.

2. Semua kawasan wisata yang diteliti mempunyai tingkat aksesibilitas rendah bila diukur dari Surabaya dan Gresik sedangkan dari kota Lamongan dan Tuban bervariasi dari sedang sampai tinggi.

3. Kawasan wisata yang dapat dijadikan pusat pertumbuhan kepariwisataan Kabupaten Lamongan adalah Goa Maharani, namun masih perlu penambahan berbagai fasilitas dan atraksi.

Berdasarkan kondisi potensi obyek-obyek wisata maupun indikator pengembangan kepariwisataan dapat disarankan sebagai berikut :

1. Untuk lebih mengoptimalkan pengembangan kepariwsataan di Kabupaten Lamongan kawasan wisata Goa Maharani dan Pantai Tanjung Kodok dapat dijadikan satu kawasan pengembangan

2. Promosi lebih ditekankan pada wisatawan dari luar Kabupaten Lamongan

3. Pengembangan kawasan wisata Waduk Gondang dilakukan dengan model yang berbeda.

\section{Daftar Pustaka}

Charles,E.G., 1996. Planning For Tourism Development, Quantitative Approach New York : Peager Publisher Inc.

Page,S.J.and Hall,C.M., 1999. The Geography of Tourism And Recreation, Environment,Place and Space.London:Routledge.

Pearce,A.G.1995. Change In Tourism: People, Places, Processes.London:Routledge.

Pearce,D.1986. Topics In Applied Geography Tourist Development. Christchurc: New Zaeland University of Conterbury.

Pendit,N.S. 2003 .IImu Pariwisata.Sebuah Pengantar. Jakarta: Pradnya Paramita.

Subyantoro,P.C.2001. Prospek Kawasan Wisata Goa Maharani Di Kabupaten Lamongan Untuk Pengembangan Daerah Tujuan Wisata Nasional/Internasional. Laporan Penelitian. LP UNESA.

Suharyono dan Amin, 1994. Pengantar Filsafat Geografi. Jakarta: Dirjen Pendidikan Tinggi Departemen Pendidikan dan Kebudayaan.

Sujali.1989.Geografi Pariwisata dan Kepariwisataan. Yogyakarta: Fakultas Geografi Universitas Gadjah Mada. 